\title{
Carbonic Anhydrase in the Human Fetal Lung
}

\author{
GUDMAR LÖNNERHOLM ${ }^{(35)}$ AND PER WISTRAND \\ Department of Pediatrics, University Hospital, Uppsala, Sweden and Department of Medical Pharmacology, \\ University of Uppsala, Uppsala, Sweden
}

\begin{abstract}
Summary
Lung tissue from human fetuses, with gestational ages ranging between 14-26 wk, was studied by histochemical and biochemical methods. The findings were similar in all tissues tested, without apparent correlation to gestational age. Staining that indicated carbonic anhydrase activity was found in the capillary endothelium and in the epithelium of some segments of the peripheral airways. The ciliated epithelium of the central airways was unstained. The distribution of the enzyme in the human fetal lung differed clearly from that in the adult human lung, where little or no enzyme has been found in the airway epithelium. The mean carbonic anhydrase activity in whole homogenates of fetal lung tissue was 24 enzyme units per $g$ wet weight of tissue. Ninety $\%$ of this activity was recovered in the supernatant fraction. Assay of this fraction by a radioimmunosorbent technique showed the presence of the carbonic anhydrase isoenzyme HCA-C corresponding to $380 \mathrm{ng}$ enzyme per mg tissue protein. Small amounts of HCA-B were also found but are thought to be attributable to contaminating erythrocytes; thus, the data suggest that both the capillary endothelium and the lung epithelium contain $\mathrm{HCA}-\mathrm{C}$, an isoenzyme of carbonic anhydrase known to be involved in electrolyte transport in many tissues.
\end{abstract}

\section{Speculation}

Carbonic anhydrase is probably involved in lung liquid secretion in the fetal lamb. The present data suggest that this enzyme plays a similar role in the human fetal lung.

The presence of the enzyme carbonic anhydrase (carbonate dehydratase EC 4.2.1.1.) has been demonstrated in homogenates of fetal lung tissue from lambs (1) and monkeys (3). It seems to be involved in lung liquid secretion, because in vivo administration of acetazolamide, a specific inhibitor of carbonic anhydrase (15), suppressed the rate of secretion and changed the composition of the secreted fluid in the fetal lamb (1). No study of carbonic anhydrase in the fetal human lung seems to have been reported.

The aim of the present work was to study the detailed distribution of the enzyme in human fetal lungs by a histochemical method, and to determine the activity and isoenzyme pattern of carbonic anhydrase in lung tissue homogenates from human fetuses using a new radioimmunosorbent technique.

\section{MATERIALS AND METHODS}

Tissue preparation. Lung tissue was obtained from eight human fetuses, removed by cesarean section. In seven cases, with gestational ages varying between 14-23 wk, legal abortion was performed in healthy women for nonmedical reasons; these women had not been taking any drug regularly. In one case (gestational age $26 \mathrm{wk}$ ), the fetus was removed because of severe mitral valve disease in the mother. This woman had taken digoxin, quinidine, warfarin and phenytoin throughout the pregnancy. Gestational age was determined from the patient history and the fetal crownheel length (26). Tissue preparation began within $30 \mathrm{~min}$ after removal of the fetus. Some pieces of lung tissue were frozen immediately, whereas others were fixed by immersion in $2.5 \%$ glutaraldehyde $+0.1 \mathrm{M}$ phosphate buffer $(\mathrm{pH} 7.4)$ at $4^{\circ} \mathrm{C}$ for about $24 \mathrm{~h}$. After a brief rinse in distilled water, some pieces of fixed tissues were rapidly frozen, whereas others were embedded in the water-soluble resin JB-4 (Polysciences, Inc., Warrington, PA, USA) as described by Ridderstråle (21). Frozen tissues were stored at $-70^{\circ} \mathrm{C}$ until used.

Histochemical staining procedure. Lung tissue from all eight fetuses was stained for carbonic anhydrase activity according to the method of Hansson $(5,6,11)$. In this method sections are floated on a medium containing $157 \mathrm{mM} \mathrm{NaHCO}, 1.75-3.5 \mathrm{mM}$ $\mathrm{CoSO}_{4}, 11.7 \mathrm{mM} \mathrm{KH}_{2} \mathrm{PO}_{4}$ and $53 \mathrm{mM} \mathrm{H}_{2} \mathrm{SO}_{4}$. The pH of the medium is 5.8 immediately after mixing. Carbonic anhydrase catalyzes the dehydration of $\mathrm{HCO}_{3}^{-}$to $\mathrm{CO}_{2}$ and $\mathrm{OH}^{-}$. Continuous local $\mathrm{OH}^{-}$formation at sites of enzyme activity causes deposition of a basic cobalt-phosphate complex, which is converted to $\mathrm{CoS}$; thus, a black precipitate is formed where carbonic anhydrase is present. Sections $2-6 \mu \mathrm{m}$ thick of frozen tissues were sectioned in a cryostat at $-20^{\circ} \mathrm{C}$ and incubated for $1-12$ min with $1.75 \mathrm{mM}$ $\mathrm{CoSO}_{4}$ in the medium. Sections $0.5-2 \mu \mathrm{m}$ thick of resin-embedded tissues were incubated for $1-8 \mathrm{~min}$ with $3.5 \mathrm{mM} \mathrm{CoSO}_{4}$ in the medium (21). Some sections were counterstained with hematoxylin and eosin. The sections were mounted in Eukitt.

Biochemical methods. Tissues from three fetuses (gestational ages 19,21 and $26 \mathrm{wk}$ ) were assayed. After thawing and gentle blotting on absorbent paper, the tissue was homogenized in nine parts of distilled water (except for the 26-wk-old fetus where 12 parts of distilled water were used), which contained $1 \mathrm{mM}$ EDTA (sodium salt) to protect the enzyme from inactivation by heavy metal ions. An aliquot of the homogenate was taken for analysis of protein and for assay of carbonic anhydrase activity. The homogenate was centrifuged at $100,000 \times \mathrm{g}$ for $60 \mathrm{~min}$. The supernatant was assayed for carbonic anhydrase activity and for its content of protein, hemoglobin and the two human carbonic anhydrase isoenzymes HCA-B and HCA-C. The pellet was resuspended and assayed for carbonic anhydrase activity. Hemoglobin and carbonic anhydrase activity were determined in a blood sample from each fetus. These data were used to correct for contamination of the tissues with blood.

Carbonic anhydrase activity of the tissue homogenates was measured by the changing $\mathrm{pH}$ method of Philpot and Philpot (20). This involves determination of the time taken to lower the $\mathrm{pH}$ (from 10 to 7.4) of $1 \mathrm{ml}$ of carbonate buffer as seen by the change in color of phenol red at $0^{\circ} \mathrm{C}$ in a $7 \mathrm{ml}$ volume. One enzyme unit is the amount of enzyme that halves the reaction time.

Carbonic anhydrase proteins were assayed by a radioimmunosorbent technique (30), using antibodies selective against the human erythrocyte isoenzymes HCA-C (anti-HCA-C) and HCA$B$ (anti-HCA-B). The antibodies were produced as previously described by Wistrand and Rao (29). The sensitivity of this method is $0.2 \mathrm{ng}$ enzyme protein $/ \mathrm{ml}$ of tissue fluid and the precision is $5 \%$ in duplicate determinations.

Protein was assayed by the method of Lowry et al. (10) and hemoglobin by the cyan-methemoglobin technique (8). 


\section{RESULTS}

Histochemistry. The lung tissues shown in Figures $1-4$ are from fetuses with gestational ages of 14,21,23 and $26 \mathrm{wk}$, respectively. In these tissues, as in all fetal lungs tested, the staining for carbonic anhydrase activity gave similar results. In all lungs, clear staining of the pulmonary capillaries was seen and the whole circumference of the capillaries was similarly stained (Fig. 1, 2A, 3, 4A). Other pulmonary vessels were unstained, and so were the interstitial or mesenchymal cells. The epithelium of the peripheral airways showed varying degrees of staining: in some segments of the airways there was distinct cytoplasmic staining, but in others weak or no staining (Fig. 1A, 2A, 3, 4A). The exact location of the stained segments of the epithelium is not clear at present. The ciliated epithelium of the bronchi and bronchioli was always unstained, however (Fig. 4B). Erythrocytes were unstained after short incubation times (Fig. 4A), and only weakly stained after long incubation times. This is not astonishing because the erythrocytes during early fetal life contain low concentrations of carbonic anhydrase (see below).

Throughout the study the specificity of the staining procedure was checked by incubation of sections in the presence of $10 \mu \mathrm{M}$ acetazolamide (Diamox, American Cyanamid Company, Pearl River, New York). This concentration of acetazolamide completely abolished visible staining (Fig. 2B), whereas the presence of $10 \mu \mathrm{M}$ of the inactive control substance $\mathrm{Cl} 13850$ (14), a $\mathrm{N}^{5}-t$ butyl analogue of acetazolamide (American Cyanamid Company), did not interfere with the staining. Sections incubated in the medium without any substrate, i.e., sodium bicarbonate, remained unstained.

Biochemistry. The carbonic anhydrase activity of the three fetal lungs tested differed about 3-fold (Table 1), without any apparent correlation to gestational age. The difference might partly be due to the slightly (1.5-fold) varying levels of protein extracted from the lung tissues during preparation. Approximately $90 \%$ of the activity in the whole homogenate was recovered in the supernatant

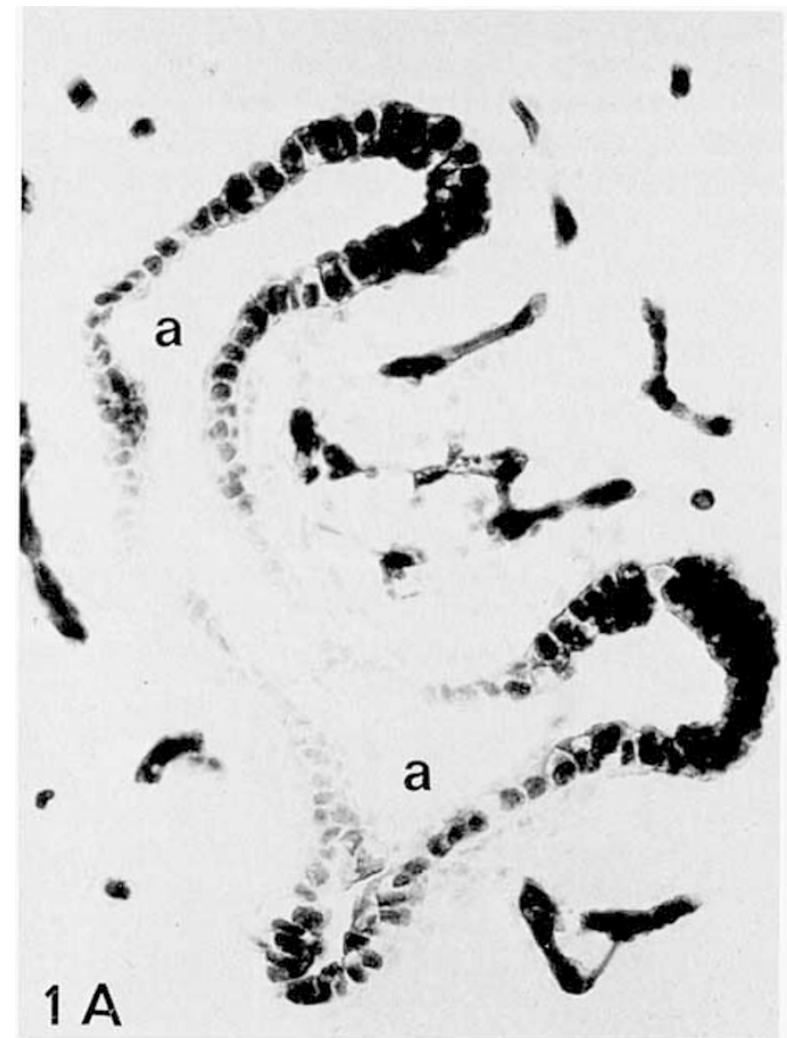

fraction, and about $10 \%$ in the particulate fraction. Analysis of the supernatant fraction showed the presence of carbonic anhydrase isoenzyme $\mathrm{HCA}-\mathrm{C}$, with similar concentrations in all three lungs (Table 1). Only small amounts of HCA-B were found, and they were probably attributable to contaminating erythrocytes. The mean enzyme activity in the blood from the three fetuses was 14.7 enzyme units per ml whole blood (range 11.8-16.6). The mean HCA-C concentration in fetal blood was 131 (range 115-159) and the mean HCA-B concentration 73 (range 34-123) ng enzyme per $\mathrm{mg}$ hemoglobin.

\section{DISCUSSION}

Evidence for the validity of the histochemical method used here has been produced by several investigators $(5,11,22)$. Muther $(18$, 19) has questioned the specificity of the method, but the controversy caused by his criticism has been fully resolved by recent work in our (12) and other laboratories $(9,16,24,25)$. In the present study, tissues were prepared in different ways for the incubation. The findings were essentially independent of the mode of preparation (although resin-embedded tissue allowed more detailed observations than frozen tissue), which argues against artifacts caused by diffusion or inactivation of the enzyme.

The fetal human lungs tested histochemically covered a wide range of gestational ages, 14-26 wk, and thus represented lungs in different states of morphologic development (7). In spite of the differences in microscopic appearance the staining for carbonic anhydrase activity gave surprisingly similar results in all lungs: the endothelium of pulmonary capillaries and parts of the epithelium lining the peripheral airways took the stain.

The possibility that the capillary staining in the lung could be due to enzyme from ruptured erythrocytes is strongly contradicted by the finding that capillaries in other fetal tissues, e.g., the intestine, were unstained in all the fetuses tested (Lönnerholm, unpublished observations). Staining of pulmonary capillaries has also been demonstrated in rat and monkey lungs thoroughly

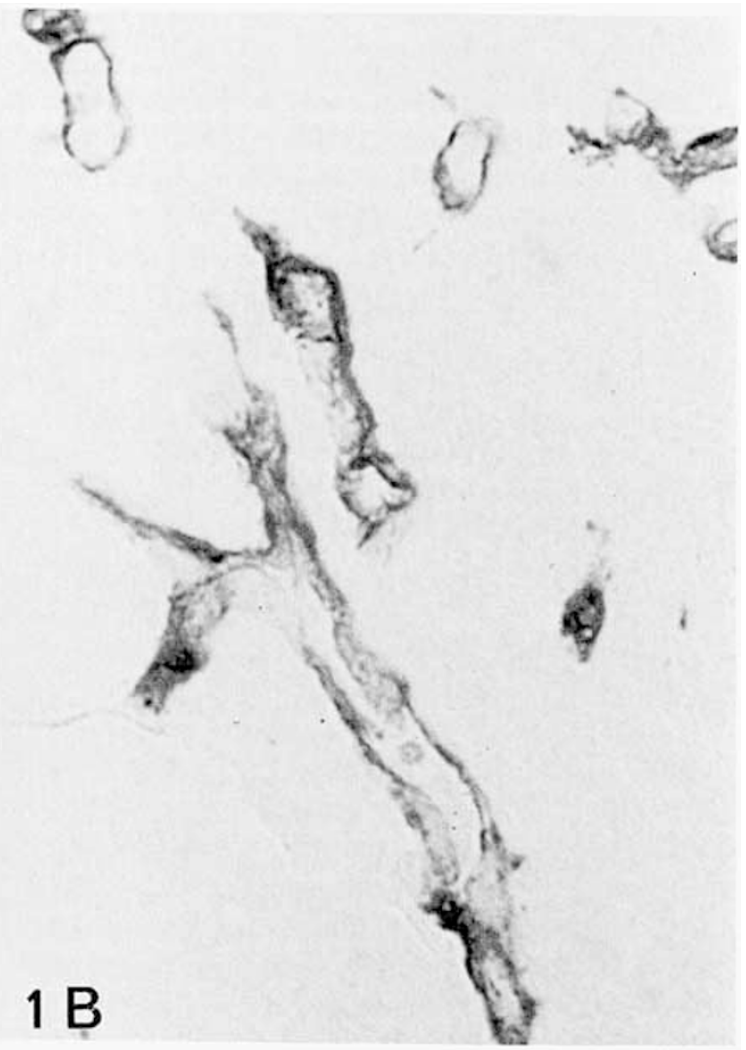

Fig. 1. Fetal human lung; gestational age $14 \mathrm{wk}$. $A$, the columnar epithelium of the branching airways (a) is partly stained. Capillaries in surrounding tissue show clear staining. Frozen tissue. Incubation time $6 \mathrm{~min}(\times 560)$. B, stained capillaries surrounded by unstained mesenchymal cells. Resinembedded tissue. Incubation time $6 \min (\times 800)$. 


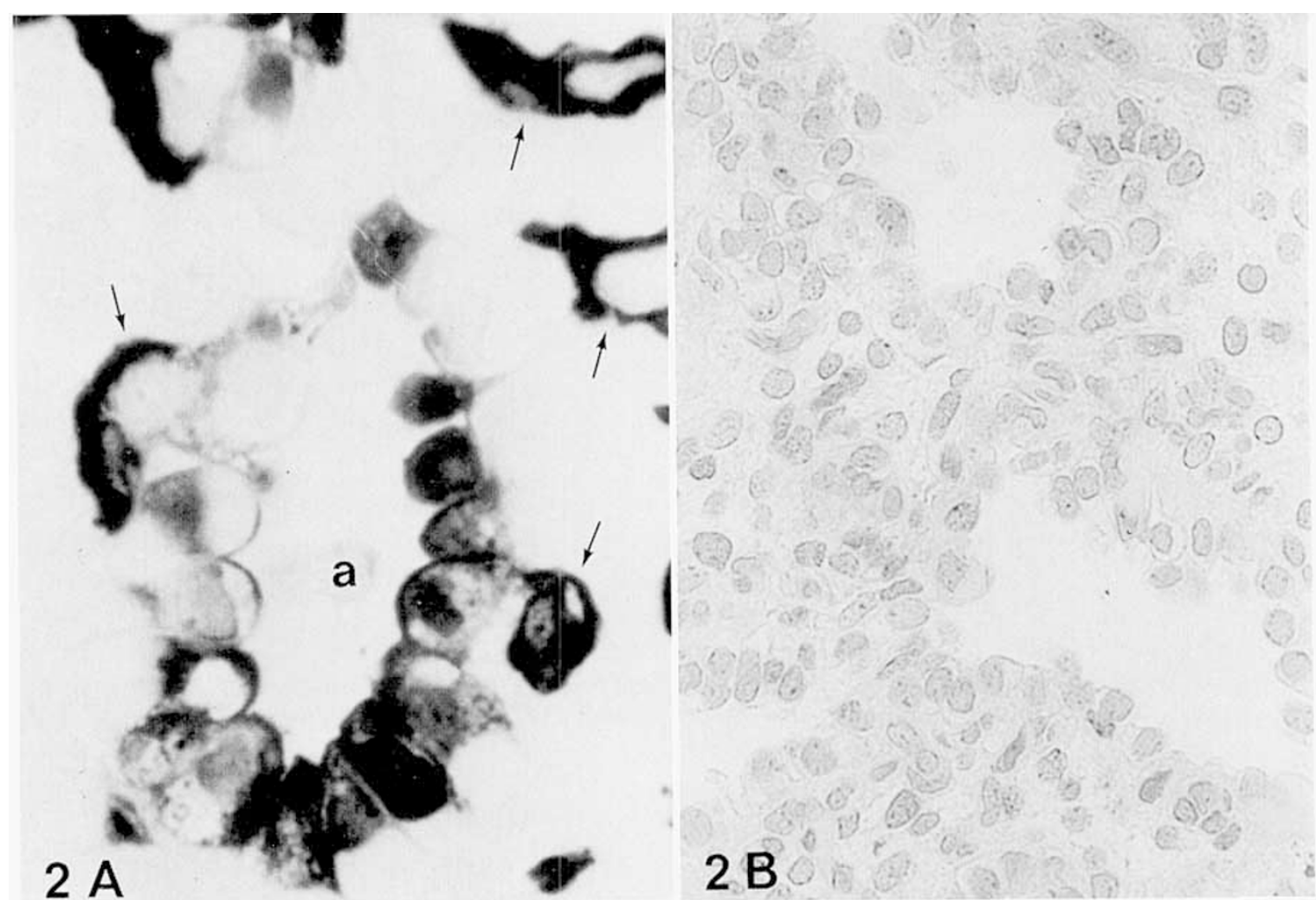

Fig. 2. Fetal human lung; gestational age 21 wk. $A$, the epithelium of a peripheral airway (a) shows varying degrees of staining: in some cells there is clear cytoplasmic staining (lower part of $a$ ), but in others no or weak staining (upper part). Capillaries are heavily stained (arrows). Resin-embedded tissue. Incubation time $8 \mathrm{~min}(\times 1400), B, 10 \mu \mathrm{M}$ acetazolamide in the incubation medium has completely inhibited all staining. Same tissue and incubation time as $\mathrm{A}$. Counterstaining with hematoxylin and eosin $(\times 560)$.

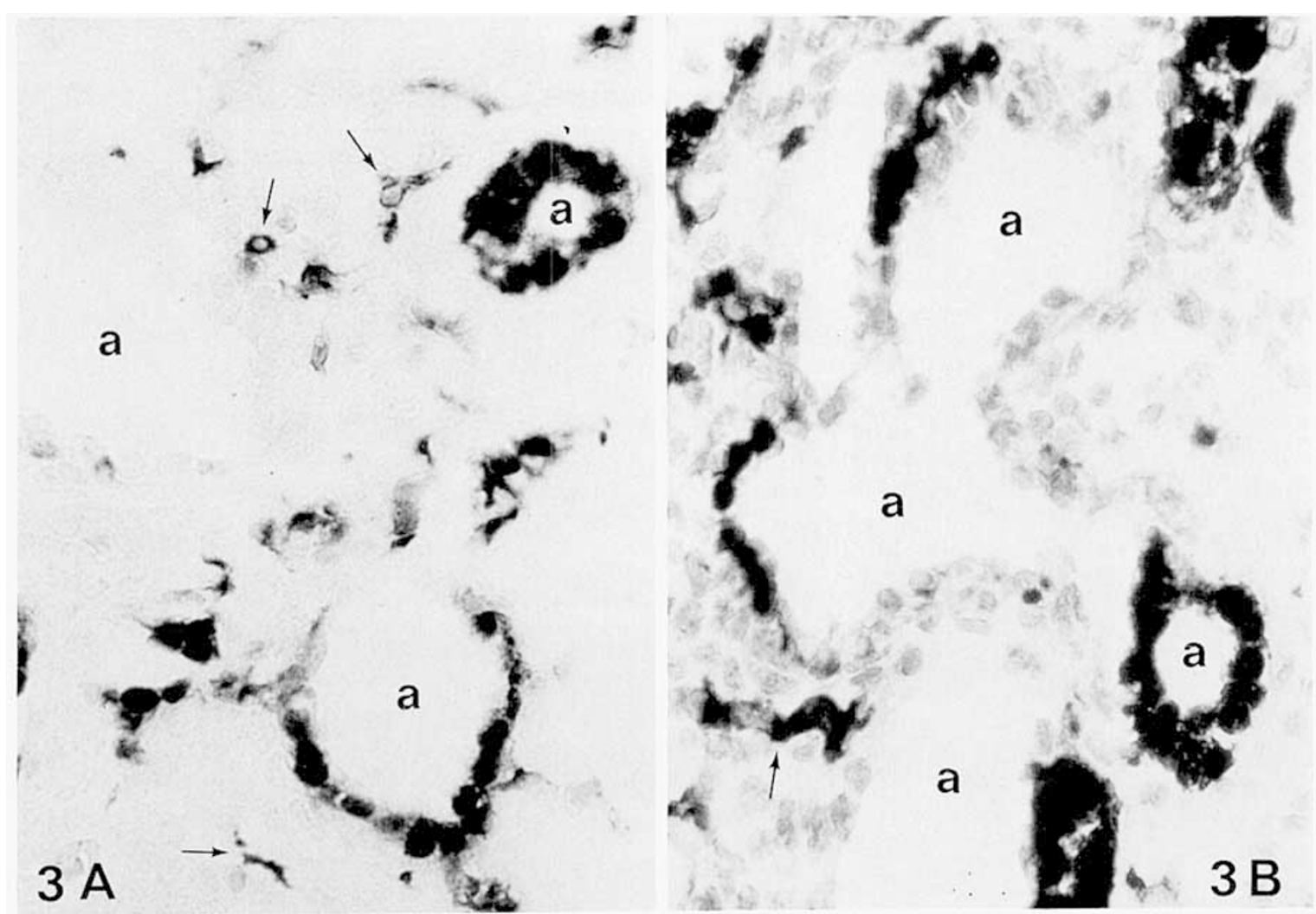

Fig. 3. Fetal human lung; gestational age $23 \mathrm{wk}$. The cuboidal epithelium of the airways $(a)$ is partly stained. Collapsed capillaries in the surrounding tissue (some are indicated by arrows) are also stained. Frozen tissue. $A$, Incubation time 6 min $(\times 560)$. $B$, Incubation time 9 min. Counterstaining with hematoxylin and eosin $(\times 560)$. 


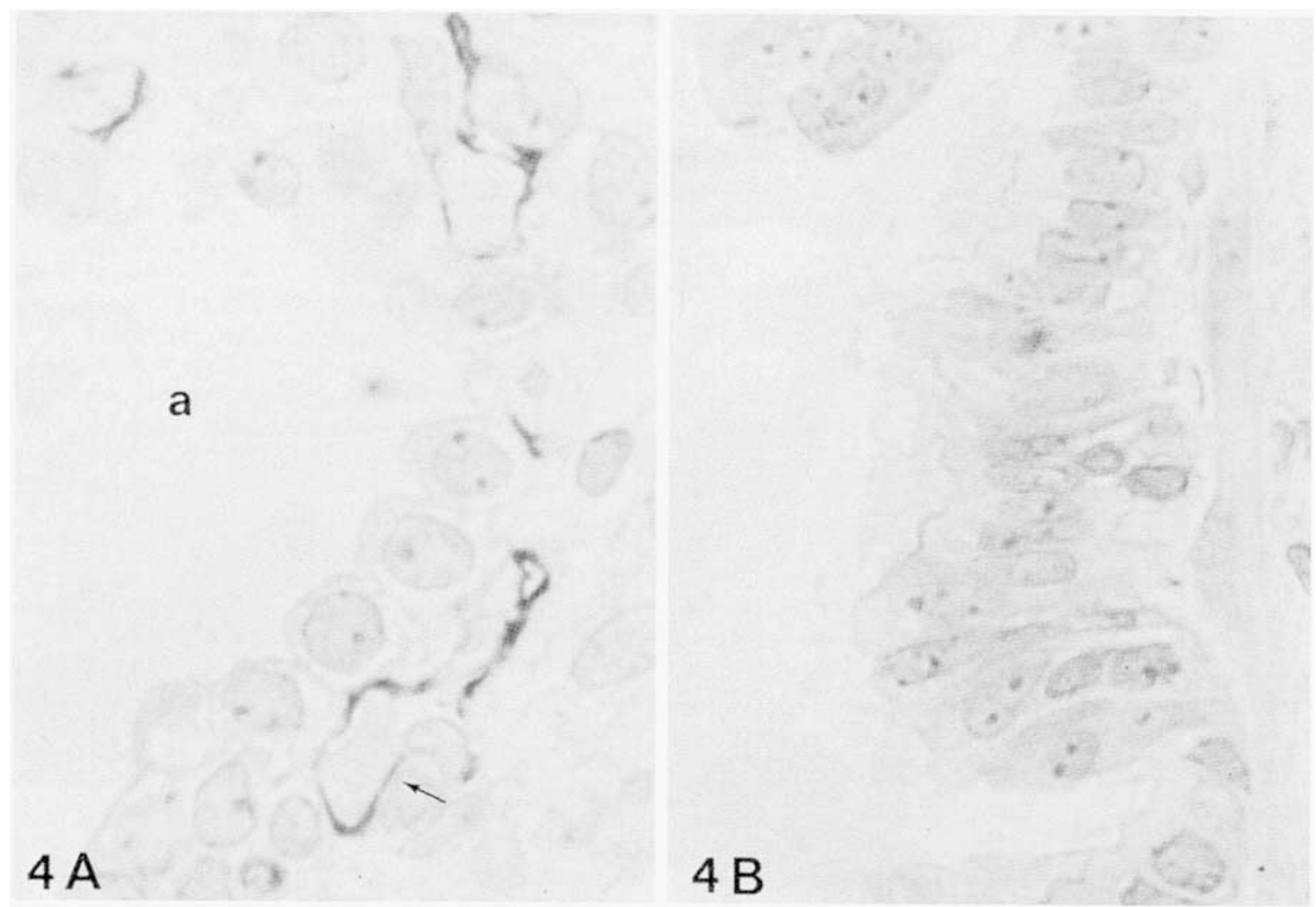

Fig. 4. Fetal human lung; gestational age $26 \mathrm{wk}$. Resin-embedded tissue. Counterstaining with hematoxylin and eosin. $A$, Unstained, low cuboidal epithelium of peripheral airway $(a)$. Capillaries located close to the epithelium are stained. One contains unstained erythrocytes (arrow). Incubation time $3 \mathrm{~min}(\times 1400) . B$, Ciliated bronchial columnar epithelium shows no carbonic anhydrase staining. Incubation time 8 min $(\times 1400)$.

Table 1. Carbonic anhydrase in homogenates of fetal human lung tissue

\begin{tabular}{|c|c|c|c|c|c|c|}
\hline \multirow[b]{2}{*}{ Gestational age (wk) } & \multicolumn{3}{|c|}{ Not corrected for blood contamination ${ }^{1}$} & \multicolumn{3}{|c|}{ Corrected for blood contamination } \\
\hline & $\begin{array}{c}\text { E.u./g wet weight of } \\
\text { tissue }^{2}\end{array}$ & $\begin{array}{l}\% \text { Enzyme activity } \\
\text { in supernatant }\end{array}$ & $\begin{array}{c}\text { \% Enzyme activity } \\
\text { in pellet }{ }^{3}\end{array}$ & $\begin{array}{l}\text { E.u./mg protein in } \\
\text { supernatant }{ }^{4}\end{array}$ & $\begin{array}{l}\mathrm{HCA}-\mathrm{B} \mathrm{ng} / \mathrm{mg} \\
\text { protein in super- } \\
\text { natant }^{5}\end{array}$ & $\begin{array}{l}\text { HCA-C ng/mg pro- } \\
\text { tein in supernatant }\end{array}$ \\
\hline 19 & 23.8 & 112 & 9 & 0.75 & 2 & 427 \\
\hline 21 & 11.2 & 84 & 7 & 0.27 & 4 & 363 \\
\hline 26 & 36.9 & 78 & 17 & 0.86 & 2 & 358 \\
\hline Mean & $24.0^{8}$ & 91 & 13 & 0.63 & 3 & $383^{9}$ \\
\hline
\end{tabular}

${ }^{1}$ The enzyme activity in the whole homogenate and the pellet could not be corrected for blood contamination, because the turbidity prevented the determination of their hemoglobin concentrations.

${ }^{2}$ E.u. is enzyme units.

$3 \%$ of the activity in the whole homogenate.

${ }^{4}$ Only $0.2-2 \%$ of the total activity of the supernatant fraction was attributable to carbonic anhydrase from red blood cells.

${ }^{5} 34-62 \%$ of the total amount was attributable to red blood cells.

${ }^{6} 1-2 \%$ of the total amount was attributable to red blood cells.

${ }^{7}$ Not enough material to perform assay.

${ }^{8}$ Values of some adult human tissues are given for comparison: kidney cortex 242 , kidney papilla 157 (27) and ciliary processes 15 E.u./g of tissue (28).

${ }^{9}$ The levels of immunoassayable HCA-C in adult human kidney cortex and papilla and ciliary processes were 1300,600 and $1900 \mathrm{ng} / \mathrm{mg}$ tissue protein, respectively. Negligible levels of HCA-B were found in these tissues $(27,28)$.

perfused free of blood (13). A histochemical study of the adult human lung has also shown staining of the pulmonary capillary endothelium, but in contrast to the fetal lung, little or no staining of the pulmonary epithelium (13). The level of carbonic anhydrase activity and isoenzyme content of the adult human lung is not known.

The enzyme activities and isoenzyme patterns in the lung tissue homogenates were also similar in the three fetuses tested, with gestational ages ranging from 19-26 wk. The enzyme activity both in the capillary endothelium and in the epithelium evidently originates from cytoplasmic $\mathrm{HCA}-\mathrm{C}$, because only this isoenzyme, after correction for the presence of $\mathrm{HCA}-\mathrm{C}$ and $\mathrm{HCA}-\mathrm{B}$ in contaminating erythrocytes, was found in the supernatant of the lung homogenate. The activity of the pellet was not further analyzed. HCA-C, which is the most widely distributed of the cytoplasmic isoenzymes, is an extremely efficient catalyst of the forward and reverse reaction: $\mathrm{H}_{2} \mathrm{O}+\mathrm{CO}_{2} \leftrightharpoons \mathrm{H}_{2} \mathrm{CO}_{3}$. It is found in erythrocytes and many secretory epithelia where it is thought to have an effect on the transfer of $\mathrm{CO}_{2}, \mathrm{H}^{+}, \mathrm{HCO}_{3}^{-}$and $\mathrm{Cl}^{-}$(15). Its levels in the fetal lung compared to those in human kidney and ciliary epithe- 
lium are given in Table 1 . No values are available for the adult human lung. In human tissues the "low" activity isoenzyme HCA$\mathrm{B}$ has only been demonstrated with certainty in erythrocytes (30) in gall bladder mucosa (4) and in the colonic mucosa (Lönnerholm and Wistrand, unpublished observations) (32). Its function is not well understood in any of these tissues (2).

The mean carbonic anhydrase activity in whole blood from the fetuses was about $3 \%$ of that in whole blood from adults. The HCA-C concentration was about $8 \%$ and the HCA-B concentration about $0.6 \%$ of that in adult blood $(4,30)$. These low values are not surprising, because the concentrations of HCA-B and HCA-C in the blood of newborn full-term infants are known to be less than $10 \%$ of those in adult blood, with even lower values in premature infants (17).

The appearance of pulmonary carbonic anhydrase during early intrauterine life and its invariable presence in all the fetuses examined suggest that the enzyme is catalytically active and plays a functional role in the fetal human lung. Direct evidence for this is lacking; however, Adamson and Waxman (1) have reported the presence of carbonic anhydrase in homogenates of lung tissue from fetal lambs. Further, they found that administration of acetazolamide lowered the rate of lung liquid secretion by about $65 \%$ and significantly decreased the chloride concentration in this secreted fluid; thus, carbonic anhydrase seems to be involved in lung liquid secretion in the fetal lamb. The present demonstration that there is considerable carbonic anhydrase activity in the human fetal lung epithelium, whereas there is little or no such activity in the adult lung epithelium, supports the idea of a similar role of the enzyme in the lung of the human fetus. Liquid secretion in the lung does not seem to take place after birth (23). When and how a decline in the carbonic anhydrase activity in the epithelial cells is brought about and the lung liquid secretion is "turned off" is not known at present.

\section{REFERENCES AND NOTES}

1. Adamson, T. M. and Waxman, B. P.: Carbonate dehydratase (carbonic anhydrase) and the fetal lung. In: Lung liquids, Ciba Found. Symp., 38: 221 (1976).

2. Carter M. J.: Carbonic anhydrase: isoenzymes, properties, distribution and functional significance. Biol. Rev., 47: 465 (1972).

3. Fisher, D. A.: Carbonic anhydrase activity in fetal and young rhesus monkeys. Proc. Soc. Exp. Biol. (NY), 107: 359 (1961).

4. Funakoshi, S. and Deutsch, H. F.: Human carbonic anhydrases VI. Levels of isozymes in old and young erythrocytes and in various tissues. J. Biol. Chem. 246: 1088 (1971)

5. Hansson, H. P. J.: Histochemical demonstration of carbonic anhydrase activity Histochemie, 11: 112 (1967)

6. Hansson, H. P. J.: Histochemical demonstration of carbonic anhydrase activity in some epithelia noted for active transport. Acta Physiol. Scand., 73: 427 (1968).

7. Hislop, A. and Reid, L.: Growth and development of the respiratory systemanatomical development. In: J. A. Davies and J. Dobbing: Scientific Foundations of Paediatrics p. 214-254 (Heineman, London, 1974).

8. Kampen, E. J. and Zijlstra, W. G.: Standardization of hemoglobinometry II. The hemoglobin-cyanide method. Clin. Chem. Acta, 6: 538 (1961).

9. Loveridge, N.: A quantitative cytochemical method for measuring carbonic anhydrase activity. Histochem. J., 10:361 (1978).

10. Lowry, O. H., Rosebrough, N. J., Farr, A. L., and Randall, R. J.: Protein measurement with the Folin phenol reagent. J. Biol. Chem., 193: 265 (1951)

11. Lönnerholm, G.: Carbonic anhydrase histochemistry. A critical study of Hansson's cobalt-phosphate method. Acta Physiol. Scand., Suppl. 418 p. 1-43. (1974).

12. Lönnerholm, G.: Carbonic anhydrase in the rat liver and rabbit skeletal muscle; further evidence for the specificity of the histochemical cobalt-phosphate method of Hansson. J. Histochem. Cytochem., 28: 427 (1980).

13. Lönnerholm, G.: Pulmonary carbonic anhydrase in man, monkey and rat. $\mathbf{J}$. Appl. Physiol., 52: 352 (1982).

14. Maren, T. H.: $\mathrm{N}^{5}$-substituted 2-acetylamino-1,3,4 thiadiazole-S-sulfonamides: metabolic conversion and use as control substances. J. Pharm. Exp. Ther., 117: 385 (1956).

15. Maren, T. H.: Carbonic anhydrase: chemistry, physiology, and inhibition. Physiol. Rev., 47: 595 (1967).

16. Maren, T. H.: Kinetics, equilibrium and inhibition in the Hansson histochemical procedure for carbonic anhydrase. A validation of the method. Histochem. $J$., I2: 183 (1980).

17. Mondrup $M$ and Anker, N.: Carbonic anhydrase isoenzymes in the erythrocytes of new-born premature and full-term infants. Clinica Chimica Acta, 61: 127 (1975).

18. Muther, T. F.: A critical evaluation of the histochemical methods for carbonic anhydrase. J. Histochem. Cytochem., 20: 319 (1972).

19. Muther, T. F.: On the lack of specificity of the cobalt-bicarbonate method for carbonic anhydrase. J. Histochem. Cytochem., 25: 1043 (1977).

20. Philpot, F. J. and Philpot, J. St. L.: A modified colorimetric estimation of carbonic anhydrase. Biochem. J., 30: 2191 (1936)

21. Ridderstråle, Y.: Intracellular localization of carbonic anhydrase in the frog nephron. Acta Physiol. Scand., 98: 465 (1976).

22. Rosen, S. and Musser, G. L.: Observations on the specificity of newer histochemical methods for the demonstration of carbonic anhydrase activity. J. Histochem. Cytochem., 20: 951 (1972).

23. Strang, L. B.: Growth and development of the lung: fetal and postnatal. Ann. Rev. Physiol., 39: 253 (1977).

24. Sugai, N. and Ito, S.: Carbonic anhydrase, ultrastructural localization in the mouse gastric mucosa and improvements in the technique. J. Histochem. Cytochem., 28: 511 (1980).

25. Sugai, N. and Ito, S.: Ultrastructural localization of exogenous carbonic anhydrase activity in ileal absorptive cells of suckling rats. J. Histochem. Cytochem., 28: $563(1980)$.

26. Watson, E. H. and Lowrey, G. H.: Growth and development of children. (Year Book Medical Publishers, Inc., Chicago, 1967).

27. Wistrand, P. J.: Human renal cytoplasmic carbonic anhydrase. Tissue levels and kinetic properties under near physiological conditions. Acta Physiol. Scand., 109: 239 (1980)

28. Wistrand, P. J. and Garg, L. C.: Evidence of a high-activity C type of carbonic anhydrase in human ciliary processes. Invest. Ophthalmol., 18: 802 (1979).

29. Wistrand, P. J. and Rao, S. N.: Immunologic and kinetic properties of carbonic anhydrase from various tissues. Biochem. Biophys. Acta, 154: 130 (1968).

30. Wåhlstrand, T., Knuuttila, K. -G., and Wistrand, P. J.: A radioimmunosorbent technique for the assay of B- and C-types of carbonic anhydrase in human tissues. Scand. J. Clin. Lab. Invest., 39: 503 (1979).

31. Wåhlstrand, T. and Wistrand, P. J.: Carbonic anhydrase $C$ in the human renal medulla. Upsala J. Med. Sci., 85: 7 (1980).

32. HCA-B has been claimed to be present also in the medullary portion of human autopsy kidneys $(4,29)$; however, these kidneys contained large amounts of erythrocytes, as indicated by high hemoglobin level, which renders the correction for blood contamination more difficult. In a recent study (31) where well perfused donor kidneys were used, only HCA-C was found.

33. This study was approved by the Ethical Committee of the University of Uppsala. 34. The authors thank Mrs. Mona Schenholm who gave skilful technical assistance.

35. Requests for reprints should be addressed to: Dr. Gudmar Lönnerholm, Department of Medical Pharmacology, Biomedicum, Box 573, S-75123 Uppsala. Sweden.

36. This research was supported by the Swedish Medical Research Council (grant nos 5413 and 2874).

37. Received for publication June 19, 1981

38. Accepted for publication January 13, 1982. 